Georgetown University Law Center

Scholarship @ GEORGETOWN LAW

1995

\title{
Whose Dispute Is It Anyway? A Philosophical and Democratic Defense of Settlement (In Some Cases)
}

Carrie Menkel-Meadow

Georgetown University Law Center, meadow@law.georgetown.edu

This paper can be downloaded free of charge from:

https://scholarship.law.georgetown.edu/facpub/1767

83 Geo. L.J. 2663

This open-access article is brought to you by the Georgetown Law Library. Posted with permission of the author. Follow this and additional works at: https://scholarship.law.georgetown.edu/facpub

Part of the Dispute Resolution and Arbitration Commons, and the Legal Remedies Commons 


\title{
Whose Dispute Is It Anyway?: A Philosophical and Democratic Defense of Settlement (In Some Cases)
}

\author{
CARRIE MeNKEL-MeAdOW*
}

\section{INTRODUCTION}

I have often thought myself ill-suited to my chosen profession. I love to argue, but I am often too quick to say both, "yes, I see your point" and concede something to the "other side," and to say of my own arguments, "yes, but, it's not that simple." In short, I have trouble with polarized argument, debate, and the adversarialism that characterizes much of our work. Where others see black and white, I often see not just the "grey" but the purple and red-in short, the complexity of human issues that appear before the law for resolution.

In the last decade or so, a polarized debate about how disputes should be resolved has demonstrated to me once again the difficulties of simplistic and adversarial arguments. Owen Fiss has argued "Against Settlement"; Trina Grillo and others have argued against mediation (in divorce cases and other family matters involving women) ${ }^{2}$ Richard Delgado and others have questioned whether informal processes are unfair to disempowered and subordinated groups, ${ }^{3}$ Judith Resnik has criticized the (federal) courts' unwillingness to do their basic job of adjudication; ${ }^{4}$ Stephen Yeazell has suggested that too much settlement localizes, decentralizes, and delegalizes dispute resolution and the making of public law; ${ }^{5}$ Kevin C. McMunigal has argued that too much settlement will make bad advocates; ${ }^{6}$ and David Luban and Jules Coleman, among other philosophers, have criticized the

\footnotetext{
* Professor of Law, UCLA School of Law and Georgetown University Law Center; Co-Director, UCLA Center for Conflict Resolution.

1. See Owen M. Fiss, Against Settlement, 93 Yale L.J. 1073 (1984).

2. See Trina Grillo, The Mediation Alternative: Process Dangers for Women, 100 YALE L.J. 1545 (1991); see also Penelope E. Bryan, Killing Us Softly: Divorce Mediation and the Politics of Power, 40 Buff. L. Rev. 441 (1992); Lisa G. Lerman, Mediation of Wife Abuse Cases: The Adverse Impact of Informal Dispute Resolution on Women, 7 HARV. WOMEN's L.J. 57 (1984).

3. See Richard Delgado et al., Faimess and Formality: Minimizing the Risk of Prejudice in Alternative Dispute Resolution, 1985 WIS. L. REV. 1359 (arguing that alternative dispute resolution disadvantages minority disputants).

4. See Judith Resnik, Managerial Judges, 96 HARv. L. Rev. 376 (1982) [hereinafter Resnik, Managerial Judges] (criticizing managerial role increasingly assumed by judges); Judith Resnik, Failing Faith: Adjudicatory Procedure in Decline, 53 U. CHI. L. REV. 494 (1986) [hereinafter Resnik, Failing Faith] (advocating revision of Federal Rules of Civil Procedure).

5. See Stephen C. Yeazell, The Misunderstood Consequences of Modern Civil Process, 1994 WIS. L. REV. 631 (describing consequences of decline in proportion of trials to filed civil cases).

6. See Kevin C. McMunigal, The Costs of Settlement: The Impact of Scarcity of Adjudication on Litigating Lawyers, 37 UCLA L. REV. 833 (1990) (arguing that lack of trial experience among today's lawyers threatens effective functioning of litigators in legal system premised on adjudication).
} 
moral value of the compromises that are thought to constitute legal settlements. ${ }^{7}$ On the other side, vigorous proponents of alternative dispute resolution, ${ }^{8}$ including negotiation, mediation, arbitration, and various hybrids of these forms of preadjudication settlement, criticize the economic and emotional waste of adversarial processes and the cost, inefficiency, and political difficulties of adjudication, as well as its draconian unfairness in some cases. ${ }^{9}$

In my view, this debate, while useful for explicitly framing the underlying values that support our legal system, has not effectively dealt with the realities of modern legal, political, and personal disputes. ${ }^{10}$ For me, the question is not "for or against" settlement (since settlement has become

7. See David Luban, Bargaining and Compromise: Recent Work on Negotiation and Informal Justice, 14 PHIL. \& PUB. AFF. 397 (1985) (discussing how negotiation requires the compromise of principles); David Luban, Settlements and the Erosion of the Public Realm, 83 Geo. L.J. 2619 (1995) [hereinafter Luban, Settlements]; Jules Coleman \& Charles Silver, Justice in Settlements, 4 SOC. PHIL. \& POL'Y 102 (1986) (arguing that settlements are often morally objectionable). See generally Compromise in Ethics, Law, and Politics (J. Roland Pennock \& John W. Chapman eds., 1979) [hereinafter CoMpromise IN ETHICs] (discussing compromise in context of various disciplines).

8. I have often been included in this school by others, see Luban, Settlements, supra note 7, at 2639 n.86, though I view myself, as indicated by the opening of this essay, as both a proponent and a critic. See Carrie Menkel-Meadow, Pursuing Settlement in an Adversary Culture: $A$ Tale of Innovation Co-opted or "The Law of ADR," 19 FLA. ST. U. L. REv. 1 (1991) [hereinafter Menkel-Meadow, Pursuing Settlement] (discussing how adversarial system coopts and transforms innovations of dispute resolution); Carrie Menkel-Meadow, For and Against Settlement: The Uses and Abuses of the Mandatory Settlement Conference, 33 UCLA L. REV. 485 (1985) (discussing arguments for and against mandatory settlement conferences). I combine the enthusiasm of a practitioner (as a mediator, negotiator, and arbitrator) with the critical eye of the scholar looking at structural and long-term effects of the aggregation of individual cases.

9. For a sampling of such arguments, see Robert A. BARuch BuSH \& Joseph P. Folger, The Promise of Mediation (1994) (arguing that mediation can transform disputants into more psychologically and morally aware individuals); STEPHEN B. GOLDBERG ET AL., DISPUTE RESOLUTION (2d ed. 1994) (giving overview of dispute resolution theory and practice); D. Brock Hornby, Federal Court-Annexed ADR: After the Hoopla, FJC DiRECTIONS, Dec. 1994 , at 26 (considering practical issues of federal court-annexed ADR); Andrew W. McThenia \& Thomas L. Shaffer, For Reconciliation, 94 YALE L.J. 1660 (1985) (advocating settlement as a means to reconciliation); Carrie Menkel-Meadow, Toward Another View of Legal Negotiation: The Structure of Problem-Solving, 31 UCLA L. REV. 754 (1984) (describing benefits of problem-solving negotiation); Robert F. Peckham, $A$ Judicial Response to the Cost of Litigation: Case Management, Two-Stage Discovery Planning and Alternative Dispute Resolution, 37 RUTGERS L. REV. 253 (1985) (advocating case management and ADR to contain litigation costs); Frank E.A. Sander, Varieties of Dispute Processing, 70 F.R.D. 111 (1976) (advocating variety of alternative dispute resolution mechanisms to reduce judicial caseload); David N. Smith, $A$ Warmer Way of Disputing: Mediation and Conciliation, 26 (Supp.) AM. J. COMP. L. 205 (1978) (describing emergence of mediation and conciliation process).

10. When learning that I was writing yet another "defense" of settlement in response to continued critique of settlement, my colleague, Susan Gillig, remarked: "Those writing against settlement might as well write about colonizing Mars-there may be value in it, but with the 'three strikes and you're out' criminal laws and modern caseloads, civil adjudication is becoming as likely as human life on Mars."' 
the "norm" for our system), " but when, how, and under what circumstances should cases be settled? When do our legal system, our citizenry, and the parties in particular disputes need formal legal adjudication, and when are their respective interests served by settlement, whether public or private? ${ }^{12}$

As several recent commentators have noted, the role of settlement in our legal system has increased: ${ }^{13}$ some think because it is actively promoted by such developments as the Civil Justice Reform Act; ${ }^{14}$ others by simple caseload pressures, and still others because of the desirability of party-initiated or consented-to agreements to resolve disputes. While court administrators, judges, and some lawyers ${ }^{15}$ suggest that we must continue to mine the advantages of settlement for caseload reduction, ${ }^{16}$ or equity

11. For similar debates in the criminal justice system, see generally PAMELA J. UTZ, SetTling the Facts: Discretion and Negotiation in Criminal Court (1978) (discussing how different models of plea bargaining can be made more or less responsive to criminal defendant and system needs); Albert W. Alschuler, The Changing Plea Bargaining Debate, 69 CAL. L. REV. 652 (1981) (arguing that plea bargaining is inherently unfair and irrational process); Albert W. Alschuler, Mediation with a Mugger: The Shortage of Adjudicative Services and the Need for a Two-Tiered Trial System in Civil Cases, 99 HARv. L. REv. 1808 (1986) (discussing how shortcomings of legal system have distorted settlement process).

12. As another "false dichotomy" in this debate, scholars often assume that settlements are almost exclusively privately arranged and thus deprive the rest of us of: (1) access to knowledge of the wrongdoing in particular cases; (2) the values assessed for settlements and evaluation of injuries or harms; and (3) the precedential value of an enunciated principle for resolving future disputes. Many settlements are, of course, public and recently have received as much press attention and legal consideration as any published case. See, e.g., Warren Brown, GM Settles 4 Lawsuits, WASH. Post, Sept. 12, 1995, at D1; Thomas M. Burton, New Offer Readied in Breast Implant Case, WALL ST. J., Oct. 3, 1995, at B4; see also Symposium, Mass Tortes: Just Desserts, 80 CORNell L. Rev. 811 (1995) [hereinafter Cornell Symposium]. In my own contribution to that symposium, I argued for court and public scrutiny, with standards, of some settlements. See Carrie Menkel-Meadow, Ethics and the Settlements of Mass Torts: When the Rules Meet the Road, 80 CoRNELl L. Rev. 1159 (1995); see also William Schwarzer, Settlement of Mass Tort Class Actions: Order Out of Chaos, 80 CorNell L. Rev. 837 (1995) (suggesting criteria for court (and thus, public) review of class action settlements).

13. See Marc Galanter \& Mia Cahill, "Most Cases Settle": Judicial Promotion and Regulation of Settlements, 46 STAN. L. REv. 1339 (1994) (exploring merits of judicial promotion of settlements); Yeazell, supra note 5, at 638-39.

14. 28 U.S.C. $\$ \S 471-82$ (1988 \& Supp. V 1993) (requiring the development of civil justice delay and cost reduction plans, authorizing creation of local advisory committees to consider court policy, and encouraging variety of alternative dispute resolution techniques to accomplish these results); see Lauren K. Robel, Fractured Civil Procedure: The Justice Reform Act of 1990, 46 Stan. L. Rev. 1447 (1994) (arguing that Civil Justice Reform Act does not authorize deviations from Federal Rules of Civil Procedure); Lauren K. Robel, Grass Roots Procedure: Local Advisory Groups and the Civil Justice Reform Act of 1990, 59 BROOK. L. REV. 879 (1993) (assessing success of Civil Justice Reform Act based on survey of Advisory Group members)

15. See, e.g., Alternative Dispute Resolution Issue, FJC Directions, Dec. 1994, at 1 (discussing development and use of alternative dispute resolution in federal courts).

16. A recent series of articles in the Journal of Legal Studies has begun to explore the economics and efficiency of ADR from the perspective of litigants, judges, the legal system, and larger society. It is important to recognize that not all of these classes of people or institutions have the same interests, economically or otherwise. See generally Robert H. 
among claimants, especially in mass torts or class action settings, many legal scholars continue to express concern with the use of settlement as a device for resolving our legal disputes. ${ }^{17}$

The difficulty with the debate about settlement vs. adjudication is that there are many more than two processes, ${ }^{18}$ as well as other variables that affect the processes, to consider. The diverse interests of the participants in the dispute, ${ }^{19}$ the legal system, and society may not be the same. Issues of fairness, legitimacy, economic efficiency, privacy, publicity, emotional catharsis or empathy, ${ }^{20}$ access, equity among disputants, and lawmaking may differ in importance for different actors in the system, and they may vary by case-this is the strength of our common law system.

In his accompanying essay, David Luban argues that settlement is prob-

Gertner \& Geoffrey P. Miller, Settlement Escrows, 24 J. LEGAL STUD. 87 (1995) (examining settlement escrows as method to reduce delay and promote settlement); Bruce L. Hay, Effort, Information, Settlement, Trial, 24 J. LEGAL STUD. 29 (1995) (examining role of asymmetric information in determining outcome of trials); Steven Shavell, Alternative Dispute Resolution: An Economic Analysis, 24 J. LEGAL STUD. 1 (1995) (distinguishing between ex ante ADR and ex post ADR). See also Jonathan R. Macey, Judicial Preferences, Public Choice, and the Rules of Procedure, 23 J. LEGAL STUD. 627 (1994) (arguing that judges' self-interest in caseload reduction and elimination of "tedious" cases influences their behavior); Janet Cooper Alexander, Judges' Self-Interest and Procedural Rules: Comment on Macey, 23 J. LEGAL STUD. 647 (1994) (responding to Macey's arguments).

17. My colleague Stephen Yeazell is concerned that more and more cases are disposed of either by settlement or by motion, thus reserving more and more power to lawyers and trial judges, with little review and scrutiny by higher levels of the judiciary. Marc Galanter and Mia Cahill, in reviewing the available empirical work on judicial promotion of settlements, are skeptical of whether settlement proponents have established any strong evidence that settlement itself is good policy-there are some costs and some benefits, but settlements, like adjudication, are neither good nor bad. See Galanter \& Cahill, supra note 13, at 1387-91.

18. Recent scholarship on this subject continues to treat "adjudication" on the one hand and "ADR" on the other as if they were uniform processes, even where they may "meld" into each other. Modern scholars continue to conflate all ADR processes (even when describing them as different, they continue to attribute the same qualities to all forms of ADR) just as they view adjudication as if it were the same in a local small claims court in a rural community and a federal district court in a major city (not to mention the differences in "adjudicatory" effects of such rulings as summary judgment). See generally Judith Resnik, Many Doors? Closing Doors? Alternative Dispute Resolution and Adjudication, 10 OHIO ST. J. ON DISP. RESOL. 211 (1995) (examining and conflating attitudes towards ADR and adjudication).

19. For example, cost savings for litigants in individual cases may result in larger costs for the system if ADR is offered by the courts. See generally Shavell, supra note 16, at 24 (examining why parties use ADR and what social interest is in ADR).

20. There has been a slight increase in the attention paid to the emotional aspects of disputing in recent scholarly and practical writing about settlements. See, e.g., E. AllaN LiNd \& TOM R. TYler, The Social Psychology of Procedural Justice (1988) (examining standards for evaluation of different processes and procedures); JACK B. WEINSTEIN, INDIVIDUAL JUSTICE IN MASS TORT LiTIGATION (1995) (describing practical issues faced by participants in mass tort litigation); Carrie Menkel-Meadow, Measuring Both the Art and Science of Mediation, 9 NEGOTIATION J. 321 (1993) (examining standards for evaluation of mediators and suggesting that empathy and empathy training are essential parts of mediation process); Carrie Menkel-Meadow, Is Altruism Possible in Lawyering?, 8 GA. ST. U. L. REV. 385 (1992) (discussing how adversary system suppresses altruism and human empathy). 
lematic because it reduces public participation in the business of dispute resolution and, consequently, reduces production of rules and precedents-in short, settlement leads to an "erosion of the public realm."21 Settlement works in favor of "private peace" and in opposition to "public justice." 22 Luban, like other critics of settlement, suggests that the legal system is designed to engage us (and our judges, lawyers, and litigants) in the public discourse of lawmaking and policy debate that concerns itself with justice and self-defined societal values-in our case, democratic deliberation. By judging and enunciating rules, judges set baselines for political endowments and entitlements and alternately close and open debates by reviewing facts and articulating the rules and values that underlie particular legal positions. ${ }^{23}$ Settlements, on the other hand, represent cruder "compromises" of raw bargaining skill and extrajudicial power imbalances (economics, legal skill, and repeat play experience). Luban acknowledges that we can no longer imagine a "world without settlement." We need it simply to muddle through the hundreds of thousands of disputes our modern society produces. Unlike Fiss, he acknowledges that not all disputes are occasions for "structural transformation" or public elucidation of basic values. ${ }^{24}$ And, as he suggests realistically, "[t]oo many cases will

21. Luban, Settlements, supra note 7, at 2619.

22. Others, like Laura Nader, have decried for years the emphasis on "harmony" values over "justice" values, for particular individual disputants, as well as for the public. See, e.g., Laura Nader, Controlling Processes in the Practice of Law: Hierarchy and Pacification in the Movement to Re-Form Dispute Resolution, 9 OHIO ST. J. ON DisP. ReSOL. 1 (1993) (criticizing acquiescence to ADR and harmony ideology).

23. See Luban, Settlements, supra note 7, at 2637.

24. Id. at 2631. Having just spent two months mediating auto accident cases in Los Angeles civil courts, I am struck by the difficulty of characterizing disputes. On one hand, all of these cases were "simple" car accidents: factual disputes about small amounts of money, with issues ranging from full liability disputes to disagreements about the value of medical expenses and property damage. The parties simply wanted their money in most cases (at least as articulated by their respective lawyers). On the other hand, however, any single one of these cases could also be taken as representative of any number of very important public or democratic issues. Insurance companies were clamping down on alleged widespread fraud by plaintiffs, their doctors, and their lawyers in overclaiming. See STEPHEN CARROLL ET AL., RAND Corporation, The Costs of Excess Medical Claims for Automobile Personal INJURIES 3-4 (1995) (describing extent of excess claiming by auto accident victims). Virtually all of these disputes involved the multicultural/racial issues that are sub rosa in increasingly diverse Los Angeles. Lawyers made arguments about how the racial composition of juries would affect the valuation of cases. And standards of human behavior and responsibility were constantly being negotiated in these sessions, both with reference to the law "on the books" and in reality (i.e., "Get real, nobody stops at a yellow light or even slows down at a busy intersection in L.A."). Thus, ironically, I now find myself more in agreement with Owen Fiss than in the past. It is not only our larger "structural" lawsuits that raise important issues of public values, but even the "smallest" of cases has significant public, as well as private, possibilities of value clarification. If, as in my ideal world, disputes were not so easily monetized, see Menkel-Meadow, supra note 9, at 791, 795, the occasion for articulation of values would be even greater-when should we apologize, take responsibility, and provide care and other nonmonetary items in resolution of a dispute? 
make bad law." 25 With an increase of cases, and trial and appeals courts making more and more law, there are likely to be irreconcilable inconsistencies in decisional law, producing a virtual "tower of Babel" of legal precedents. ${ }^{26}$

Thus Luban shifts the focus to a consideration of when and how settlements should take place. His ultimate focus is on the need to keep settlements public and to decry the loss to democratic discourse when too many settlements are kept secret. ${ }^{27}$ Luban argues that secret settlements deprive us not only of "result" information, but the "facts" of discovery, necessarily "privatizing" information to which a democratic society should have access. He suggests that those who continue to favor secret settlements prefer the "problem-solving" (dispute resolution) conception of our legal system to "public production of rules and precedents" or the "public goods and discourse" function. Thus Luban is willing to tolerate settlement, but only if it is open to the "sunshine" laws and serves "at least some of the public values of adjudication," 28 by keeping the settlement process and its information open to the public.

In this essay, I hope to explore some of the same questions that Professor Luban has framed for us-how can we decide which settlements to be for and which to be against? In other words, how can we tell good settlements from bad ones, and when should we prefer adjudication to settlement? Like others who have written on this subject, both recently ${ }^{29}$ and in the past, ${ }^{30} \mathrm{I}$ do not think there are easy answers to this question; but more problematically, I want to suggest that it will be very difficult for us to specify in advance criteria for allocation to particular processes. In the words of current academic cachet, much depends on the context - of

25. Luban, Settlements, supra note 7 , at 2646.

26. Id. at $2642-46$.

27. This issue is controversial and gaining increasing attention, not only from scholars, but also from the Judicial Conference (which recently debated changes to the rules on protective orders, see Saundra Torry, Judges Reject Record-Secrecy Rule, WASH. POST, Mar. 15, 1995, at A8), state legislatures, and judiciaries, which are debating changes in rules of civil procedure and substantive regulation of secrecy and access to settlements. See Wayne D. Brazil, Protecting the Confidentiality of Settlement Negotiations, 39 HASTINGS L.J. 955 (1988) (describing circumstances in which courts permit discovery and admission at trial of confidential settlement negotiations); Carrie Menkel-Meadow, Public Access to Private Settlements: Conficting Legal Policies, 11 Alternatives to High Cost Litig. 85 (1993) (noting increasing number of states revising civil discovery rules to allow more public access); Arthur R. Miller, Confidentiality, Protective Orders, and Public Access to the Courts, 105 Harv. L. Rev. 427 (1991) (arguing against reform of discovery rules that would limit judges' discretion to issue protective orders).

28. Luban, Settlements, supra note 7, at 2659.

29. See, e.g., Galanter \& Cahill, supra note 13; Luban, Settlements, supra note 7; Yeazell, supra note 5.

30. See, e.g., Lon L. Fuller, The Forms and Limits of Adjudication, 92 HARV. L. REV. 353 (1978) [hereinafter Fuller, Adjudication]; Lon L. Fuller, Mediation: Its Forms and Functions, 44 S. CAL. L. REV. 305 (1971) [hereinafter Fuller, Mediation]. 
disputes, of disputants, and of the system being considered. I will here complexify and problematize Luban's seemingly easy proposition-that democratic discourse requires full disclosure of legal dispute information. In this essay, I will make a case for settlement by arguing that there are philosophical, as well as instrumental, democratic, ethical, and human justifications for settlements (at least in some cases).

Those who criticize settlement suffer from what I have called, in other contexts, "litigation romanticism," 31 with empirically unverified assumptions about what courts can or will do. More important, those who privilege adjudication focus almost exclusively on structural and institutional values and often give short shrift to those who are actually involved in the litigation. I fear, but am not sure, that this debate can be reduced to those who care more about the people actually engaged in disputes versus those who care more about institutional and structural arrangements. ${ }^{32}$ I prefer to think that we need both adjudication and settlement. These processes can affect each other in positive, as well as negative ways, but in my.view, settlement should not be seen as "second best" or "worst case" when adjudication fails. ${ }^{33}$ Settlement can be justified on its own moral groundsthere are important values, consistent with the fundamental values of our legal and political systems, that support the legitimacy of settlements of some, if not most, legal disputes. These values include consent, participa-

31. See Menkel-Meadow, supra note 12, at 1173.

32. This dichotomy worries me for many reasons, but it continues to replicate itself often in these debates. Many who are critical of mediation and other "conflict handling" processes assume that ADR cannot effectuate social change, see Mark Chesler, Alternative Dispute Resolution and Social Justice, in Injustice, Social Conflict and Social Change (E. Lewis \& E. Douvan eds., 1994); Susan Silbey \& Austin Sarat, Dispute Processing in Law and Legal Scholarship: From Institutional Critique to the Reconstruction of the Juridical Subject, 66 DENV. U. L. REV. 437 (1989), and that settlement and ADR are only for individual disputes or for "therapeutic" purposes; service goals that are often described as hierarchically inferior to "bigger" questions of social justice and legal institutions. This ignores a fundamental relationship between disputants and the larger system. If disputants cannot get what they want from the justice system, they will simply not file claims and not use the system. For an eloquent elaboration of the relationship of formal legal systems to informal dispute resolution in the context of sexual harassment, see Howard Gadlin, Adapting Mediation for Sexual Harassment Complaints, in Sexual Harassment on Campus: A Guide for AdministraTORS, FACULTY AND STUDENTS (Bernice Sandler \& Robert Shoop eds., 1995).

It could be argued that Luban's concern with individual versus structural aspects of disputes replicates a variety of common dualisms in legal thinking and practice-i.e., public-private interests in lawmaking. The debate feels a lot like my experience in legal services practice with contrasts in individual case work versus "structural law reform" litigation. See generally Jack Katz, Poor People's Lawyers in Transition (1982) (describing perceived dichotomy between individual and system-wide legal service work). $C f$. Marc Feldman, Political Lessons: Legal Services for the Poor, 83 GEO. L.J. 1529 (1995) (arguing that Legal Services lawyers subscribe to dogma that divides legal activity into impact work and service work).

33. Sam Gross and Kent Syverud describe trials as "failed settlements." Samuel R. Gross \& Kent D. Syverud, Getting to No: A Study of Settlement Negotiations and the Selection of Cases for Trial, 90 MICH. L. REV. 319 (1991) (examining empirically pretrial negotiations). 
tion, empowerment, dignity, respect, empathy and emotional catharsis, privacy, efficiency, quality solutions, equity, access, and yes, even justice.

Though some have argued that compromise itself can be morally justified, ${ }^{34}$ I will here argue, as well, that compromise is not always necessary for settlement and that in fact, some settlements, by not requiring compromise, may produce better solutions than litigation. In particular, my own arguments for settlements (of particular kinds) have been often misstated or oversimplified, for the purpose of argument, so that they begin to strike me as strawpersons and cause me to question whether we are really able to understand each other when we "sharpen" the argument by "narrowing" it. $^{35}$

To summarize, it seems to me that the key questions implicated in the ongoing debate about settlement vs. adjudication are:

1. In a party-initiated legal system, when is it legitimate for the parties to settle their dispute themselves, or with what assistance from a court in which they have sought some legal-system support or service?

2. When is "consent" to a settlement legitimate and "real," and by what standards should we (courts and academic critics) judge and permit such consent? ${ }^{36}$

3. When, in a party-initiated legal system, should party consent be "trumped" by other values-in other words, when should public, institutional, and structural needs and values override parties' desire to settle or courts' incentives to promote settlement? In short, when is the need for "public adjudication" or as Luban suggests, "public

34. See, e.g., Arthur Kuflik, Morality and Compromise, in COMPRomise IN ETHICS, supra note 7 , at 63 .

35. In particular, authors who have "reduced" my arguments for settlement as solely a "needs-based" argument for settlement, see, e.g., Galanter \& Cahill, supra note 13, at 1359; Silbey \& Sarat, supra note 32 , at 485 , or a "problem-solving-satisfaction" mode of dispute settlement, see, e.g., BuSH \& FOLGER, supra note 9, at 58; Luban, Settlements, supra note 7, at 2632 \& n.60, fail to account for my analysis of the politics and ethics of settlement. See Menkel-Meadow, supra note 9, at 829-40.

There are two themes of critique that $I$ have taken very seriously and that do seem to raise significant practical problems with the theoretical bases of my arguments for settlements. Several critics have cogently suggested that the model of negotiated settlements that I (and others, e.g., Roger Fisher \& William URY, GetTing to Yes (Bruce Patton ed., $2 \mathrm{~d}$ ed. 1991)) describe are "idealized" versions of how settlements might be achieved-they do not describe the empirical reality of lawyer negotiations. See Galanter \& Cahill, supra note 13, at 1359-60. More concretely, Herbert Kritzer has demonstrated that even if lawyers wanted to be "pie-expanding, creative problem-solvers," the structure of the contingent fee arrangement serves to monetize disputes and creates disincentives for anything but monetary solutions to legal problems. Herbert M. Kritzer, Fee Arrangements and Negotiations, 21 LAw \& SOC'Y REV. 341 (1987).

36. Note that the answer to this question remains doctrinally distinct for criminal plea bargains, civil individual actions, class actions and court reviews of some, but not all settlements. 
settlement" 37 more important (to whom?) than what the parties may themselves desire $?^{38}$

\section{Why Do Cases Settle? Some Arguments for the Justification of SETTLEMENT OVER AdJudication}

I begin with two important caveats. First, both categories of "settlement" and "adjudication" contain enough variation within them to make them almost meaningless concepts to compare in the abstract. The conduct of negotiated settlements and various stages along the adjudication spectrum include such variations of lawyer experience, skill and resources, party motivations and resources, and legal system endowments (both procedural and substantive) that we must, for the purposes of argument, consider these categories as little more than "ideal types." Thus, like David Luban and others I have criticized, for the purposes of this essay, I too will treat these categories of legal process as if they were meaningful categories of comparison, although I believe there is as much variation within these groups as between them.

Second, although I believe it is most important to understand these variations by using rigorous empirical study, ${ }^{39}$ in this essay $I$ will be offering mostly theoretical justifications for settlement, which will require further empirical verification..$^{40}$ I want to underscore that such empirical verification is essential if we are to get past the overly generalized and abstracted claims made both for and against settlement. ${ }^{41}$ In responding to

37. This is how I read Luban's claim that settlements should not be "secret."

38. Notice that it is virtually impossible to frame these questions in value-neutral ways. The philosophical and policy issues implicated are circular. Parties may seek resolution of their disputes, but we can't be sure that they have really consented to the process they use for settlement, especially when courts are so overburdened that a trial is prohibitively expensive and too long in coming. Similarly, we may think some issue needs a "public discourse" or decision, but none of the disputants may want to "step up to the plate" to have their private lives be the material of the public dispute. (Despite all the reported cases, this is typically a problem in many employment discrimination and sexual harassment suits.)

39. And thus I applaud the efforts of those researchers reported in Galanter and Cahill's excellent review of the complicated "state of the art" in empirical settlement research. See Galanter \& Cahill, supra note 13. For a look at a recent attempt to conduct a rigorous analysis of one court's efforts to create a systematic ADR program, see Joshua D. Rosenberg \& H. Jay Folberg, Alternative Dispute Resolution: An Empirical Analysis, 46 STAN. L. REV. 1487 (1994) (presenting study of ADR program in Northern District of California).

40. I will also be offering some limited qualitative empirical support for my claims from two small scale studies of mediation and from my own observations as a neutral third party in a variety of settlement settings.

41. See generally Carrie Menkel-Meadow, Durkheimian Epiphanies: The Importance of Engaged Social Science in Legal Studies, 18 FLA. ST. U. L. REV. 91 (1990) (discussing importance of empirical research about law and its operation and its relation to legal education). The particular ADR programs developed by federal courts under the Civil Justice Reform Act are currently being evaluated in two studies conducted by the Federal Judicial Center and the RAND Corporation. Final reports are due to be submitted to Congress in 1996. 
David Luban's important and significant arguments, I want to discuss some of the objections to and defenses of settlement.

\section{A. SETTLEMENT IS NOT NECESSARILY UNPRINCIPLED COMPROMISE}

In the criticism of settlement there is a common theme of the unseemliness of "compromise," considered by most writers to connote some weakness of will, morality, or principle. ${ }^{42}$ Here I wish to respond to the critique of settlement as "weak-willed" or "illegitimate compromise" in two separate ways. First, I want to make the case (again) that settlement need not be compromise at all, when "compromise" connotes the giving up of something in return for the other parties' concessions. ${ }^{43}$ Galanter and Cahill make this conceptual and definitional error when they describe one of the positive aspects of settlement as its achievement of "the golden mean": "Settlement typically involves arriving at a position between the original offers and demands of the parties. Thus, it involves a process of compromise in the sense that each has sacrificed some part of his claim in order to secure another part." 44

Indeed, as I shall argue, adjudication, with its binary or win-loss solutions, more often produces situations in which both parties and the system may have to "give up" some legitimate claims in order to terminate the dispute (as when issues are increasingly narrowed and monetized), while settlements may enable the broadening or increasing of issues for "trade" or resolution and more party interests can actually be achieved without having to "give something up." Classic illustrations in the settlement literature include the dividing of goods, not in half, but by interest, so that a piece of chocolate cake is divided into cake and icing, ${ }^{45}$ a window in another room is opened to create airflow without a draft, ${ }^{46}$ and the Sinai Peninsula is not divided at all but is neutralized with security. ${ }^{47}$ Parties

42. See, e.g., Martin P. Golding, The Nature of Compromise, in CoMPROMISE IN ETHICS, supra note 7, at 5 (arguing that each party to compromise must recognize some moral legitimacy in other's case).

43. As my colleague Jon Varat's son, Adam, once said, remarking that he and his sister did not have to eat the same food to sit down to dinner together: "How can it be a negotiation if we both don't have to give something up?'

44. Galanter \& Cahill, supra note 13 , at 1371 . This statement also conflates two aspects of compromise typical in the literature-compromise as a process of mutual concessions or cooperative or coordinated activity and compromise as a result (i.e., a split-the-difference solution). Neither necessarily entails the other. For example, see Golding's description of literal "log-rolling" in which a motorist assists a farmer in removing a log fallen in the road that neither has the strength to move alone. The motorist and the farmer "coordinate" or "cooperate" in a process of physical effort so that the motorist can continue his journey and the farmer can cut the tree for firewood or other uses. Thus, both achieve their respective ends without "giving anything up." Golding, supra note 42, at 13-14.

45. See Menkel-Meadow, supra note 9, at 771.

46. See FISHER \& URY, supra note 35 , at 40.

47. See id. at 41-42. 
who identify their complementary, not necessarily competitive, needs and interests can achieve more of what they want by trading for what they value more but what the other party values less. ${ }^{48}$ Thus, "compromise" in Galanter and Cahill's sense, like litigation outcomes that award all or nothing, assume we all value the same thing equally. If we don't actually value the same things equally, then negotiated settlement is more democratic: it allows the full representation of our real needs and interests by permitting fuller expression of those interests and by allowing "trades" or non-"split-the-difference" divisions that more accurately track party desires and facilitate outcomes that maximize, rather than minimize or compromise, party goals.

Second, even granting that some settlements will look like "compromises" in which certain issues or interests are traded or "given up" for dispute resolution or for other purposes, some compromise itself can be justified on moral, political, and philosophical grounds, and is often more satisfactory to the parties and "better" for the legitimacy of the legal system. Negotiated compromises are not lawless, rightless "give-aways," as the antisettlement literature too often assumes. ${ }^{49}$ Indeed, on this point of critique the arguments are often contradictory-either settlements are bad because they simply represent the results of brute bargaining power or they are unprincipled ("split-the-difference" solutions). Note, however, that they cannot often be both at the same time. Why would someone with sufficient bargaining power to "win" give up half? Indeed, as philosopher Martin Golding has suggested, a "split-the-difference" compromise actually connotes a certain moral legitimacy or recognition of "equality" by the parties. If the parties had rational, principled, or moral reasons, or enough brute strength (including economic resources) to win a dispute, why would they accede "half" to the other side unless the settlement recognized some equal rational, principled, moral, or power-based reason for doing so ${ }^{50}$

48. See generally George C. Homans, Social Behavior (1961); I. William Zartman \& Maureen R. Berman, The Practical Negotiator 13-14, 174-76 (1982) (noting that parties tend to try to fit their differing valuations of items into common decision). A most vivid illustration of Homans's principle - that human needs are often complementary, not competitive-was brought home to me when I was describing my work on negotiation to colleagues at a faculty cocktail party some years ago. Slowly the bowl of cocktail snacks was worn down as we picked our way through nuts, pretzels, wheatchex, popcorn, puffed rice, raisins, and goldfish, each of us choosing our favorite-there was no competition at all! The variety of human tastes permitted us to consume the available goods evenly without a single conflict or competitive preference. I realize the real world does not often provide the variety necessary to permit expression of such different interests, but it still is useful to consider how "expanding" rather than "limiting" what is available can reduce the need for "split-thedifference" compromises of single or more limited goods.

49. For an eloquent argument that legal negotiations provide their own internal ethics of truthfulness and legitimation, see Eleanor Holmes Norton, Bargaining and the Ethics of Process, 64 N.Y.U. L. REv. 493 (1989).

50. See Golding, supra note 42 , at 17 . 
The concern that settlements deprive both litigants and the larger public realm of normatively based solutions lies at the core of Luban's and Fiss's criticisms. Yet I would argue that a settlement process may actually be more "just" in the need for both less compromise and less narrowing of legally cognizable issues. That the parties will "compromise" without principle assumes two things: First, that items in dispute are valued equally by the parties, and second, that agreement requires giving them up. The legal system that Luban, Fiss, and others extol, however, is largely responsible for reducing most legal disputes, not to disputes of public values and resource allocation, but to monetized disputes about dollars. When they are submitted to judges and juries with such legal principles as comparative negligence, these monetized disputes are just as likely to result in "split-the-difference" results in court as settlement. ${ }^{51}$ Noncompromise settlements offer the promise that more than money can be at stake and that the parties can negotiate such other items as future relationships and conduct, apologies, in-kind trade, new contracts, etc. In my view, it is litigation, not settlement, ${ }^{52}$ that has led to monetization of disputes, for money has become the proxy for all legal harms and hurts. ${ }^{53}$ Judges and juries award dollars when they cannot order behavior that parties will agree to undertake on their own. ${ }^{54}$

More often and more troubling to those who are concerned about justice, a litigated outcome will produce binary win-lose results that often do not capture the "just reality." As John E. Coons argued so elegantly many years ago, compromise (or at least nonbinary solutions) may represent more "precise justice" when we cannot be absolutely certain about the facts, or when competing principles of law dictate different and sometimes opposed underlying values. ${ }^{55}$ Coons argued that courts (as well as settling parties) should be allowed to render fifty-fifty or other allocative verdicts when either unresolved factual doubt or legal ambiguities or contradictions make winner-take-all results unjust. ${ }^{56}$ Thus, for me, until litigation is permitted to recognize the ambiguities and contradictions in

51. For an eloquent argument that this is a good thing, that the legal system distorts with its need for noncompromised results, see John E. Coons, Approaches to Court Imposed Compromise: The Uses of Doubt and Reason, 58 Nw. U. L. REv. 750 (1964) [hereinafter Coons, Approaches] (discussing court-imposed compromise in civil litigation); John E. Coons, Compromise as Precise Justice, in COMPROMISE IN ETHICS, supra note 7, at 190 [hereinafter Coons, Compromise] (defining compromise in civil litigation).

52. See Luban, Settlements, supra note 7, at 2646-47.

53. Luban and Kritzer are right that the structure of attorneys' fees strongly influences what disputes can be about. To the extent that the contingent fee must be paid from money, there is little incentive to bargain for or litigate for nonmonetary items. See Kritzer, supra note 35 , at 345 .

54. I argue this at some length in Menkel-Meadow, supra note 9.

55. See Coons, Compromise, supra note 51, at 190; Coons, Approaches, supra note 51, at 754-73.

56. One can see comparative negligence as an expression of this concern. 
modern life by developing a broader "remedial imagination," 57 settlement offers the opportunity to craft solutions that do not compromise, but offer greater expression of the variety of remedial possibilities in a postmodern world. $^{58}$

Yet another objection to "compromise" settlements is the assumption that they are unprincipled. Various settlement critics have attempted to document that settlements do not track legal principles and that negotiators do not even appeal to legal endowments when settling cases. Robert Condlin has analyzed student negotiations to demonstrate the lack of appeal to law and principles in arguments made. ${ }^{59}$ Social scientist Herbert Kritzer has uncovered a pattern of "low intensity" exchange of offers in civil litigation that are made with little reference to the law. ${ }^{60}$ Janet Cooper Alexander has demonstrated that securities litigation is often settled for economic and strategic reasons that bear no relationship to the legal merits. ${ }^{61}$ These empirical findings seem to suggest that negotiators do not look to legal principles as the bases for resolving disputes. But these findings are counter to arguments made more theoretically by those who have argued that negotiations are in fact rule- and norm-based, ${ }^{62}$ as well as norm-creating, and that legal endowments in fact structure what happens in out-of-court settlements. Indeed, the often-used evocative phrase "bargaining in the shadow of the law," coined by Robert Mnookin and Lewis Kornhauser to describe divorce negotiations, ${ }^{63}$ was meant to convey how

57. I have used this phrase to characterize the limited jurisdictional power of courts to award only money damages, guilt or innocence binary verdicts, or limited injunctive relief. See Menkel-Meadow, supra note 9, at 791.

58. I will soon make an argument that our adversary system is ill-suited to the twentiethcentury postmodern observations that reality is not accurately expressed or found in dualisms or binary oppositions. Complex social and legal problems need complex (not binary) solutions. See Carrie Menkel-Meadow, The Trouble With the Adversary System in a PostModern, Multi-Cultural World, (forthcoming presentation at Legal Ethics: The Core Issues, Conference at Hofstra University Law School, Mar. 10, 1996) (unpublished manuscript, on file with The Georgetown Law Journal); see also Pauline M. Rosenau, Post-Modernism AND THE Social SCIENCES (1992).

59. Robert J. Condlin, "Cases on Both Sides": Patterns of Argument in Legal DisputeResolution, 44 MD. L. REV. 65 (1985).

60. Herbert M. Kritzer, Let's Make A Deal: Understanding the Negotiation Process in Ordinary Litigation 30-57 (1991) (describing negotiation and bargaining in litigation). See generally Herbert M. Kritzer, THE Justice Broker: LAwyers and OrdiNARY LITIGATION (1990) (examining work of ordinary lawyers in ordinary litigation).

61. Janet Cooper Alexander, Do the Merits Matter? A Study of Settlements in Securities Class Actions, 43 STAN. L. REv. 497 (1991) (arguing that settlements of securities litigation are often not reflective of regulatory and legal norms but represent settlements based on nuisance value, transaction costs, and attorney fee incentives).

62. See, e.g., Melvin A. Eisenberg, Private Ordering Through Negotiation: Dispute-Settlement and Rulemaking, 89 HARV. L. REV. 637 (1976) (examining how principles, rules, and precedents operate in private negotiation).

63. Robert H. Mnookin \& Lewis Kornhauser, Bargaining in the Shadow of the Law: The Case of Divorce, 88 YALE L.J. 950 (1979) (examining how rules and procedures used in court for adjudicating disputes affect negotiations between divorcing couples outside courtroom). 
much legal rules and bargaining endowments limit and constrain what occurs in private settlements. How can these claims be reconciled?

For those who lament the seeming absence of law or rule in settlements, several ironies are at work. First, in complaining that law does not seem to govern either settlement arguments or settlement outcomes, there is an underlying assumption that the law is just or fair and is the appropriate measure by which all disputes should be resolved. I say this is ironic because many of the critics of settlement are also critics of law (in particular instances) ${ }^{64}$ and thus should recognize the important critical and democratic function of a system of dispute resolution (settlement) that serves to criticize, avoid, or correct laws that some find unjust, inefficient, or just plain inapplicable. Second, and related to this first irony, is an unstated assumption that if law is the baseline for "justice" in settlements, then majoritarian enacted laws (by legislatures) are just for all-an unstated claim made by those who are often critical of the majoritarian enactments of law.

The more thoughtful of the settlement critics (particularly Stephen Yeazell and Judith Resnik) ${ }^{65}$ have begun to realize the "dialogic" or interactive relation between adjudication and settlement processes. What now requires recognition is that the interaction or supplementation works not only at the process level, but at the substantive level. Joint custody in divorce began as a settlement "compromise" to the draconian and severe effects of single physical custody ${ }^{66}$ and then became enacted in law ${ }^{67}$ where it is now being questioned again. ${ }^{68}$ Thus, people may choose settlement precisely because legislatively enacted "legal" solutions do not meet the underlying needs or interests of parties in particular cases. Through individually adaptive solutions in settlement we may see the limits of law and explore avenues for law reform. Settlement (and its sometime rejection of law) could just as easily be seen as a democratic expression of individual justice where rules made for the aggregate would either be unjust, or simply irrelevant to the achievement of justice in individual cases. Settlement is, thus, not "unprincipled," but may be seen as a

64. See, e.g., David Luban, Lawyers and Justice: An EthiCal Study 160-74 (1988) (defending moral activism in lawyers and urging legal reform); DAvid LUBAN, LEGAL MODERNISM 209-82 (1994) (arguing for importance of challenges to law); Judith Resnik, Tiers, 57 S. CAL. L. REv. 837 (1984) (arguing against legal limitations on jurisdiction, appellate access, and habeas corpus).

65. See generally Yeazell, supra note 5; Resnik, Managerial Judges, supra note 4; Resnik, Failing Faith, supra note 4.

66. Katherine T. Bartlett \& Carol B. Stack, Joint Custody, Feminism and the Dependency Dilemma, 2 BERKELEY WOMEN'S L.J. 9 (1986) (defending joint custody against feminist criticisms).

67. In some states, like California, as a presumption. See CaL. FaM. CodE $\$ 3080$ (West 1994).

68. See, e.g., Lynn Smith, Shuttle Diplomacy, L.A. TimEs, May 24, 1995, at E1 (detailing problems associated with joint custody). 
questioning of particular principles or the application of different individually adaptive principles. ${ }^{69}$

A related unstated assumption is that the only legitimate measure of principle in settlement is law. But settlements may draw our attention to the importance of other, nonlegal, principles that affect decisionmaking and govern human behavior. Janet Cooper Alexander's work reveals that there is a logic to the settlement of securities class actions-most often economic, not legal, logic. Thus, parties may use settlement precisely to have other, nonlegal, principles structure their disputes and relationships. I have argued extensively elsewhere ${ }^{70}$ that people and entities in disputes may have a wide variety of interests (of which legal principles may be one class) and may decide that, in any given case, social, psychological, economic, political, moral, or religious principles should govern the resolution of their dispute. This does not mean that such dispute resolution is not principled-it is just not law-principled. To the extent that law is often seen as a "metaprinciple" in our law-infused society, settlement provides another democratic point of critique. If two kinds of principles clash in a particular dispute, ${ }^{71}$ some solution will have to be found-a new "metaprinciple," a compromise or trading of principles, persuasion that one principle should govern, or a practical solution that meets the goals of the parties without formal articulation of an agreed-to principle. These variations on legal principles do not mean that settlements are not principledonly that they may be based on "nonlegal" principles that may be just as fair or just (if not more so) in particular cases.

Finally, it is too extreme to suggest that settlements are all unprincipled compromises without the force of legal authority or legitimacy. Even those settlements that actively and intentionally seem to depart from the law are accomplished precisely because a potential legal result has been considered (and is, thus, still a reference point) and has been rejected. If one party does not accede to the settlement, the default is to return to law, so

69. In this sense, I have often thought of interest-based negotiation and mediation as a legacy of legal realism. They are adaptive expressions of the interaction of the "law on the books" with the needs and interests of real people conducting transactions or having disputes.

70. Menkel-Meadow, supra note 9, at 801-04.

71. I have always had trouble with Fisher and Ury's notion that negotiators should rely on "objective criteria." See FISHER \& URY, supra note 35, at 81-94. What if the "objective criteria" are arguable or indeterminate, like so much legal argument? Consider the arguments that insureds have with their insurers about such "objective criteria" as "blue-book value" vs. "replacement value," or "cost" or "market value." In law we have only to look at the constitutional clashes in freedom of speech and equality, see, e.g., CATHARINE A. MacKinnon, Only Words (1993), abortion, see, e.g., Kristen Luker, Abortion and the POLITICS OF MOTHERHOOD (1984), the right to bear arms and police powers, and affirmative action and antidiscrimination remedies to see that appeals to "legal principles" do not always successfully conclude or resolve the dispute. 
law remains, in a sense, a constant baseline of choice and comparison. ${ }^{72}$ Furthermore, many "settlements" are made not in "the shadow of the law," but in the "shadow of the courthouse" where the parties request or require court approval or management and thus invite some legal supervision. ${ }^{73}$

We should continue to discuss whether rules and principles are fair, whether "giving up" something is necessary or justified, whether rules should be sharply delineated or allow more discretion and elasticity to meet the needs of particular circumstances, and what principles should govern particular situations. But these questions are not illuminated by a falsely simplistic model of settlements as unprincipled and unjust compromises, when settlements are not necessarily unprincipled or inefficient compromises. ${ }^{74}$ Indeed, just as David Luban argues that adjudication is the process by which legislative compromises are unraveled, reinterpreted, and redressed ${ }^{75}$ settlement is the process by which law created by adjudication is readjusted to meet the requirements of particular parties. In short, it may be that none of the processes of lawmaking, interpretation, and dispute resolution is more "holy" than another in the degree of compromise or principle by which it operates. ${ }^{76}$ Historically and generatively, they supplement, critique, and affect each other, much as our notions of separation of power and checks and balances structure our multipart government.

\section{B. SETTLEMENT DOES NOT PRECLUDE THE USE OR CREATION OF PRECEDENT}

Those who critique the lack of rules and principles and the "mushiness" of nondefinitive rulings also lament what they perceive to be the absence

72. This statement, of course, assumes that the parties know what the "legal" results would be and have the resources to effectuate them if they so choose. These are very big assumptions.

73. This is the case in court-supervised settlements, such as class action settlement approvals under Federal Rule of Civil Procedure 23(e) and settlements that seek court imprimaturs. See Bank of Am. Nat'l Trust \& Sav. Assoc. v. Hotel Rittenhouse Assoc., 800 F.2d 339 (3d Cir. 1986). Consider also that some cases that are not tried still have a court or law-based resolution-such as summary judgment or other dispositive motion judgments that are "adjudicative" without trial and often are law-based. See Herbert M. Kritzer, Adjudication to Settlement: Shading in the Gray, 70 JUDICATURE 161, 162-63 (1986) (describing adjudicating influence in cases that are resolved without trial).

74. I have not repeated at great length here the argument for a particular kind of settlement (Pareto-optimal, problem-solving, negotiated settlement) that is less likely to lead to unprincipled compromise than the most common litigation-shadowed compromise in the face of an uncertain trial verdict. See Menkel-Meadow, supra note 9, at 768-75.

75. See Luban, Settlements, supra note 7, at 2637.

76. For arguments that particular processes do have particular attributes, functions, and morality, see generally LON L. FulleR, THE MORALITY OF LAW (1969) (discussing how principles of morality apply to law); Fuller, Adjudication, supra note 30 (describing adjudication as form of social ordering); Fuller, Mediation, supra note 30 (describing characteristics of mediation); Lon L. Fuller, Collective Bargaining and the Arbitrator, 1963 WIS. L. REV. 1 (describing appropriate role for arbitration). 
of precedent in settlement processes. Implicit in Owen Fiss's classic article (and one of the most trenchant of his criticisms) is the concern that too many settlements will reduce the making of law or provide an insufficient "sample" of cases from which the courts will draw to fashion rules to govern human behavior. ${ }^{77}$ Settlement, it is argued, is used to avoid both of the key elements of a legal system based on stare decisis-governance by existing rules and the enunciation of new rules from the public application of rules to new facts. Indeed, one could extend this argument and be concerned, as is David Luban, Laura Nader, and others, that it is precisely the important "public" sort of cases that are increasingly being shielded from formal court treatment, by the recent increased use of settlements in mass torts and consumer class actions.

These issues of the loss of precedent are explored in a number of discrete legal areas. In the context of arbitration, there has long been a spirited debate about the role of law in the interpretation of collective bargaining agreements, contracts, and general dispute resolution, with a general concern that arbitration is characterized more by its arbitrariness or interpretation of party agreements than public law. ${ }^{78}$ Recent Supreme Court rulings sustaining the use of arbitration, however, seem to credit arbitration with a respect for and an ability to apply and interpret complex legal rules. ${ }^{79}$ Recently, proceduralists have become concerned about the removal of precedent by vacatur, following a postadjudication settlement, or in California, the depublication of decisions following settlement or a subsequent court order ${ }^{80}$ Here the arguments turn on who "owns" the precedent. Do the parties, whose dispute is being settled, or the public, who needs guidance from enunciated rules, control the judgment?

Once again, these concerns are based on different understandings of the role of courts and dispute resolution. For those, like Luban, who see

77. See Fiss, supra note 1, at 1085-87.

78. For an overview of arbitration law, see generally Leo KANOWITZ, CASES AND MATERIals on Alternative Dispute Resolution (1986); Ian MacNeil, American Arbitration LAW: REFORMATION, NATIONALIZATION AND INTERNATIONALIZATION (1992).

79. See, e.g., Gilmer v. Interstate/Johnson Lane Corp., 500 U.S. 20 (1991) (age discrimination); Shearson/American Express, Inc. v. McMahon, 482 U.S. 220 (1987) (RICO and securities laws); Mitsubishi Motors Corp. v. Soler Chrysler-Plymouth, Inc., 473 U.S. 614 (1985) (antitrust); cf. Alexander v. Gardner-Denver Co., 415 U.S. 36 (1974) (holding that arbitration cannot preclude litigation of statutory rights under employment discrimination laws).

80. See Judith Resnik, Whose Judgment? Vacating Judgments, Preferences for Settlement, and the Role of Adjudication at the Close of the Twentieth Century, 41 UCLA L. REv. 1471 (1994) (reviewing tensions and potential complexities in vacatur by consent); see also United States Bancorp Mortgage Co. v. Bonner Mall Partnership, 115 S. Ct. 386 (1994) (holding that settlement after filing of appeal or petition for certiorari does not justify vacatur of civil judgment under review); Neary v. Regents of the Univ. of Cal., 834 P.2d 119 (Cal. 1992) (holding California appellate courts have power to vacate trial court judgments if parties so stipulate as condition of settlement). 
adjudication as our public discourse, a case, once filed, becomes the property of the polity and is the materiel out of which we fashion our social, legal, political, and maybe even moral contracts. For those who regard our legal system as a public service for private dispute resolution, ${ }^{81}$ or as a "democratic and participatory" party initiated system, the dispute and its resolution remain the property of the parties and can be removed from the system in any way, as long as the parties consent. ${ }^{82}$ In a sense we could ask: "Whose Dispute Is It, Anyway?" 83 To whom does a dispute belong when it enters the legal system? Whose "property" is a particular dispute, and who should decide how it should be treated? ${ }^{84}$

However these important jurisprudential issues are resolved, it is important to observe here that settlements are affected by precedent-both in the ratio decidendi of arriving at particular solutions and in the creation of new precedents. Precedent makes its voice heard and power felt in every settlement, if only because one reason the parties may choose to settle is to avoid the effects of previous lawmaking. Yet just as often, settlement may be based on the uncertainty of knowing the legal result, especially if precedent is unclear or contradictory. ${ }^{85}$ To charge that settlement is ungoverned by precedent is to be grossly insensitive to the contexts in which settlements occur. For example, repeat play arbitrations and mediations are sensitive not only to the "norms" created by numerous repeat cases, ${ }^{86}$

81. Whether dispute resolution is a private or public good remains a much argued question. See generally William M. Landes \& Richard A. Posner, Adjudication as a Private Good, 8 J. LEGAL STUd. 235 (1979); Luban, Settlements, supra note 7; Shavell, supra note 16, at 2 .

82. For a thoughtful review of factors to consider in deciding when a dispute belongs in the "public domain" for disclosure purposes, see Judge Sloviter's opinion in Bank of Am. Nat'l Trust \& Sav. Assoc. v. Hotel Rittenhouse Assoc., 800 F.2d. 339, 345-46 (3d Cir. 1986). For a view that settlement processes are private and for the parties only, see Cincinnati Gas \& Elec. Gas Co. v. General Elec. Co., 854 F.2d 900, 903-04 (6th Cir. 1988).

83. Apologies to the author of Whose Life Is It Anyway?. BRIAN Clark, Whose LifE Is IT ANYWAY? (1979) (exploring tensions between doctor and patient in controlling decisions about medical treatment, with obvious parallels to legal decisionmaking, both at microlevel between lawyer and client and concerns of macrolevel choices about what is justice).

84. Though I do not explore it at length in this essay, these issues lend themselves to a more systematic analysis of the property interests implicated in dispute resolution, including the legal, not just economic, rights and interests involved in dispute resolution. See generally Nils Christie, Conflicts As Property, 17 BRIT. J. CRIMINology 1 (1977) (arguing that conflicts have independent value).

85. See George L. Priest, Reexamining the Selection Hypothesis: Learning from Wittman's Mistakes, 14 J. LEGAL STUD. 215 (1985) (advocating predictive model of which disputes will be litigated or settled); George L. Priest \& Benjamin Klein, The Selection of Disputes for Litigation, 13 J. LEGAL STUD. 1 (1984) (analyzing relationship between legal standard and rate of success of plaintiffs).

86. Such arbitrations and mediations exist in labor arbitration, child custody, and divorce mediation (where "precedent" is often felt in the bargaining endowments of court schedules for child and spousal support), construction and entertainment disputes, securities arbitration, fee disputes, farmer-creditor disputes, and, increasingly, torts (both routine auto accidents in insurance or court contexts and mass torts). 
but increasingly to published reports of settlements. ${ }^{87}$ In the last ten years, a variety of legal publishing services have begun to report the results, not only of verdicts, but of settlements as well. ${ }^{88}$ While these reports tend to be simply of monetary amounts and vary enormously by region and other contextual factors, ${ }^{89}$ they are used by practicing lawyers to guide their demands, settlements, and litigation decisions just as reported decisions do. These reports may not include the kind of elaborated legal reasoning contemplated by David Luban's public discourse about the law, but they provide at least as much guidance as jury verdicts and unreported judicial decisions. As a repeat play arbitrator myself in the Dalkon Shield litigation, I write opinions requiring both legal conclusions and fact-findings that must be elaborated and over time necessarily become affected and "constrained" by the equity of decisions in other, similar cases. Increasingly, as cases of significant public importance are covered in the news, both the precedential and publicity effects of settlements may well exceed those of reported decisions, and the public (including Luban's public realm) may be more informed than if precedents were left totally to lawyer access and interpretation. ${ }^{90}$

87. Labor arbitration awards have long been published by the Bureau of National Affairs (BNA) and Commerce Clearing House ( $\mathrm{CCH})$.

88. Settlements are reported by: LEXIS Verdicts Library, consisting of verdict and settlement reports from the Association of Trial Lawyers of America; Jury Verdict Research, Inc.; National Law Journal's Annual Verdict and Settlement Review; and a wide variety of state-wide and local verdict and settlement reporters and services. Local legal newspapers such as the L.A. Daily Journal publish weekly or monthly lists of settlements, as well as "unreported" verdicts. The California Confidential Report for Attorneys purports to be a report of jury trials, settlements, and arbitrations for all eight Southern California counties, contributed by the attorneys of record, and published as a "guide for practicing attorneys." See also Shepard's/McGraw Hill, Inc.'s Verdicts, Settlements and Tactics (1988-current); JAS Publications' Metro Verdicts Monthly (Washington, DC, Maryland, and Virginia, 1989current) (all available online). My thanks to Adrienne Adan, Law Librarian, UCLA for locating many of these sources. A variety of specialty professional associations also research, gather, and publish information about recent verdicts, settlements, and other dispositions of legal cases, in sources like the Products Liability Reporter and the Medical Malpractice Reporter. NEXIS also reports on settlements. See William G. Harrington, Being Better Informed-Electronically: Beyond Computerized Legal Research, NAT'L L.J., Apr. 1, 1985, at 14.

89. See Andrew Blum, What's A Leg Worth? It Depends, NAT'L L.J., Aug. 1, 1988, at 1.

90. As examples, one has only to look at the recent press coverage of the breast implant litigation, see David R. Olmos \& Henry Weinstein, Breast Implant Settlement in Peril, L.A. Times, May 5, 1995, at 1, a multicompany asbestos producers consortium settlement of asbestos cases, see Georgine v. Amchem Prods., Inc., 157 F.R.D. 246 (E.D. Pa. 1994), recent refusals of courts to accept settlements or consent decrees, see Judge Sporkin's opinion in the Microsoft antitrust proceeding, United States v. Microsoft Corp., 159 F.R.D. 318 (D.D.C.), rev'd, 56 F.3d 1448 (D.C. Cir. 1995), and rejection of recent car consumer class actions, see Jesus Sanchez \& Donald W. Nauss, Court Rejects GM Settlement on Value of Pickup Trucks; Autos, L.A. Times, Apr. 18, 1995, at D1. Indeed several years ago when the Southern California chapter of the Legal Defense Fund settled a housing discrimination case, it did so with a press conference specifically designed to announce the precedential effects of the largest settlement ever in a housing discrimination suit. See Penelope McMil- 
One could ask, given the proliferation of precedents by overburdened courts, if it might make sense to consider whether there is an optimal amount of court production of precedents and law to facilitate just the sort of public discourse that "adjudication" advocates, like Professor Luban, desire. Some settlement might then facilitate an "equilibrium" level of appropriate numbers and quality of judicial production to have the kind of reasoned public discourse contemplated. Thus, settlement, both by its increased use of publicity in important cases, and its ability to remove some cases from the system, might actually improve the quality of public discourse or lawmaking in the public realm, more broadly conceived of, than in traditional adjudication.

\section{THE PERILS AND NECESSITY OF SECRECY IN SETTLEMENTS}

As Professor Luban's essay makes clear, we can no longer contemplate a world without adjudication or without settlement-both are necessary to provide private citizens some opportunity to choose how they want their disputes resolved and to ensure that those cases that reach court can be fairly and thoroughly treated, ${ }^{92}$ producing the kind of public discourse that Luban contemplates. Thus, Luban's argument reduces to an argument not against settlement (for that has implicitly been conceded to necessity if not political preference or morality) but against private settlement. Luban contends that settlement should serve the same law-generating and political discourse functions that he contemplates for adjudication. This argument is appealing, but alas it is too simple, reductionist, and I submit, antidemocratic to succeed fully.

Ian, L.A. Housing Bias Suit Settled for $\$ 450,000$, L.A. Times, Feb. 20, 1990, at 1; Interview with Patrick Patterson, Esq. (Feb. 21, 1990).

91. In an important essay, George Priest has suggested that litigation delays are likely to reach certain equilibria: when the queues for trial get too long there will be more ADR and settlement activity as parties become impatient for outcomes. As more settlement and ADR accumulate and trial times decrease, more litigants will opt for trial until the wait becomes too long again. George L. Priest, Private Litigants and the Court Congestion Problem, 69 B.U. L. REV. 527 (1989). In a sense, Priest is making a market argument for the use of ADR. Competition between ADR and adjudication should result in an "optimal" time for case disposition as determined by party choice. One could argue that a similar analysis could be made for the production of precedents. Judges may encourage ADR that does not require the writing of decisions until there is enough time to write thoughtfully and fully on what remains. This, of course, does raise important issues about the bases and standards for court referral to ADR as a precedent-avoiding strategy. See Macey, supra note 16, at 634-35 (arguing that judges have wide discretion to force settlements); Carrie Menkel-Meadow, Judicial Referral to ADR: Issues and Problems Faced by Judges, FJC DIRECTIONS, Dec. 1994, at 8, 8-9 (describing issues involved in selecting cases for ADR).

92. Need I say more than if every criminal case were tried as the O.J. Simpson case, we would have virtually no civil courts in America. Indeed, District Attorney Gill Garcetti has already opined that within the next year as the "three strikes and you're out" law takes effect in California there will be virtually no room for civil trials in the 581 county courtrooms in Los Angeles. See Large Load of "3 Strikes" Cases Filed By Prosecutors, L.A. Times, Apr. 23, 1994, at B2. 
Consider two of the most successful international negotiations of our modern political life-Camp David and the Norwegian facilitation of the PLO-Israeli accords. In both instances, early advances to create an environment for negotiation and the negotiation itself required privacy and secrecy lest warring factions learned of what was in store and literally "killed" the possibility of a deal (and the negotiators as well). ${ }^{93}$ When representatives in a dispute have constituencies of widely different views of the case, and when meeting with the "enemy" itself is considered a signal of weakness, negotiations will simply not occur unless they can be held in privacy.

Thus, while critics like Luban and others ${ }^{94}$ call for the full public airing of the fact-finding and discovery process, as well as outcomes in settlements, they focus exclusively on the needs and interests of those other than the immediate parties to the particular dispute. Professor Luban argues that settlements, like "[a]ll actions relating to the rights of other human beings are wrong if their maxim is incompatible with publicity." Luban states that this "publicity principle lies at the core of democratic political morality." 96 Though I will not argue that every litigant has a right to keep his or her settlement totally private, I think it is antidemocratic and ultimately harmful to our legal and political system to insist that all disputes be publicly aired. Some would draw the distinction that once a case is filed in a public forum, such as a court, the parties have waived their rights to privatize their disputes. To the extent that many parties now

93. See generally Jimmy Carter, Keeping Faith (1982); Herbert C. Kelman, Contributions of an Unofficial Conflict Resolution Effort to the Israeli-Palestinian Breakthrough, 11 NEGotiation J. 19 (1995) (reviewing role of problem-solving workshops in peace talks); Katherine W. Meighan, Note, The Israel-PLO Declaration of Principles: Prelude to a Peace?, 34 VA. J. INT'L L. 435 (1994) (analyzing negotiation process leading to Israel-PLO agreement); Jeffery Jacobson, Farmhouse Diplomacy: The Mediation Process of the Israel-PLO Declaration of Principles (May 19, 1995) (unpublished manuscript, on file with The Georgetown Law Journal) (analyzing negotiating environment of Israel-PLO talks).

94. At various times both Professors Resnik and Yeazell have also argued against the "privatization" of fact-finding and the discovery process. See Resnik, Failing Faith, supra note 4, at 538; Yeazell, supra note 5, at 650; see also Laura Macklin, Promoting Settlements, Foregoing the Facts, 14 N.Y.U. REv. L. \& Soc. CHANGE 575 (1986) (discussing advantages of judicial fact-finding). The Association of Trial Lawyers of America (among other groups) has been mounting a national and state campaign to pass open settlement statutes, as well as change rules of procedure to shift the burden of proof in protective orders. See MenkelMeadow, supra note 27 (surveying proposed open settlement laws); Arlin R. Thrush, Public Health and Safety Hazards Versus Confidentiality: Expanding the Mediation Door of the MultiDoor Courthouse, 1994 J. DisP. Resol. 235 (surveying increased access to information in public hazard context); see also TEX. R. Civ. P. ANN. r. 76a (West 1995) (limiting instances in which court records may be sealed); FLA. STAT. ch. 69.081 (1990) (prohibiting agreements that have effect of concealing public hazards). But cf. Arthur R. Miller, Confidentiality, Protective Orders and Public Access to the Courts, 105 HARV. L. REv. 427 (1991) (defending need for protective orders against abuses of discovery rules).

95. Luban, Settlements, supra note 7, at 2648 (citing Immanuel Kant, Kant's Political WRITINGS 126 (Hans Reiss ed. \& H.B. Nisbet trans., 1970)).

96. Id. 
use private dispute resolution providers, such as JAMS-ENDISPUTE, ${ }^{97}$ to avoid public decisionmaking, one draws a dangerous line because parties seeking to privatize their disputes will simply avoid the public courts completely, ${ }^{98}$ and we will defeat the very purposes Luban wishes to serve by public settlements. If, as Luban suggests, secret settlements cause parties to "fob off" the costs of their settlements on to others (externalizing settlements by passing on costs to consumers, or forcing all litigants to bear the costs of discovery for similar transactions), then a legal system that requires full disclosure of all discovered facts and all the terms of settlements in every case likely will lead to a "private market" in dispute resolution (if it hasn't already, assisted by other factors such as the cost and delay in the public dispute resolution system). ${ }^{99}$

More important, the publicity in litigation and settlement argument seems to assume that only defendants (particularly those in products liability litigation) want to keep information secret. In fact, plaintiffs in sexual harassment, defamation, and employment cases, as well as some tort cases, have strong interests in not publicizing the underlying facts of their cases, even if they win, and most certainly if their alleged facts are not "sustained." Luban rejects the argument that a plaintiff with AIDS would not be considered a "public health and safety hazard" and claims that protective orders would offer some confidentiality. I am not as sure. Thus, some interests of party privacy and autonomy must be balanced against public and system needs. If everyone who files a lawsuit subjects himself to full disclosure by the state or media we would not be far from the world of $1984 .{ }^{100}$

Not all settlements can be public, or they simply will not occur. Thus, the harder issue is to decide how we can regulate settlements so that both public and private values of our legal and political system can be accommodated. From my perspective, Luban glosses too quickly over the question of what should be made the subject of public discourse in legal dispute

97. JAMS (Judicial, Arbitration, and Mediation Services) is a private dispute resolution service founded by retired judges. It has merged with ENDISPUTE, a service created by private lawyers and other dispute resolution professionals. Some have suggested that with the merger, ENDISPUTE'S employment of lawyers enables those who seek to be judges to do so without any formal appointment, confirmation, or service to the public court system.

98. Bryant Garth has argued that we can already see the effects of a public-private competition over dispute resolution services. See Bryant G. Garth, Privatization and the New Market for Disputes: $A$ Framework for Analysis and a Preliminary Assessment, 12 STUD. L. PoL. \& SoC'Y 367 (1992) (describing and evaluating institutions for private dispute resolution); see also Lauren K. Robel, Private Justice and the Federal Bench, 68 IND. L.J. 891 (1993) (considering effect of privatization on federal judges).

99. For example, in California many repeat play litigants, such as insurance companies, go directly to services such as JAMS-ENDISPUTE for their claims.

100. GEORGE ORWELL, 1984 (1948). As the spectacle of the O.J. Simpson trial reveals, no detail, whether of truth or speculation, will be spared if the case proves interesting enough. 
resolution. To the extent that good settlement (and here I am referring to my own "problem-solving conception," criticized by Luban as a merely "instrumentalist" conception of dispute resolution ${ }^{101}$ requires the revelation of what I call "nonlegally relevant facts," such as the parties' real and underlying needs and interests (including such factors as emotional needs and motives, future business needs, financial data, trade secrets, psychological and social issues like risk aversion, and precedential effects for other employees or family members), ${ }^{102}$ open settlement processes will severely limit the willingness of parties to settle cases for "other factors" than those that are simply legal.

In short, Luban's claim for public settlements commits two democratic errors. First, it privileges the group's (or society's) need for public discourse over the needs (dare I say rights) of individuals to seek the most comprehensive and Pareto optimal solution possible to their dispute, by sharing information that is beyond or different from what a court might order them to reveal. "Settlement facts" may indeed be different from "adjudication facts," and individual settlement needs may be different from the public's or groups' "right to know." Luban's second error is to assume (once again) that all cases, settlements, and adjudications should be "resolved" by reference to law or legally relevant principles or legally discoverable facts. Thus Luban's conception of dispute resolution, while described as democratic and organized around the public realm and public discourse, privileges law and legal principles as the only "just" way to resolve a dispute. Other information (which might not be revealed in such an open settlement process) is simply irrelevant.

Luban's analysis of the "outcomes" and treatments of two recent settlements further underscores the greater complexity of the subject at hand. What should be done publicly and what privately in our legal system has consumed scholars for many years. ${ }^{103} \mathrm{I}$ do not believe that all that is wrong with settlements and right with adjudication can be corrected by opening all disputes to publicity. I have written elsewhere at length about Georgine v. Amchem Products, Inc., ${ }^{104}$ and I suggest here that if the negotiations were not private there would have been no settlement at all. Thus, what-

101. Luban, Settlements, supra note 7, at 2633.

102. The elaboration of these categories of needs and interests can be found in MenkelMeadow, supra note 9, at 795-804.

103. See generally Symposium, The Public/Private Distinction, 130 U. PA. L. Rev. 1289 (1982) (debating borders of public and private action). Additionally, feminists have offered important arguments about the public-private splits in political discourse, as well as legal entitlements. See, e.g., Susan M. Okin, Justice, Gender and the Family (1989) (arguing that market-family dichotomy is flawed and perpetuates inequalities between women and men); Frances E. Olsen, The Family and the Market: A Study of Ideology and Legal Reform, 96 HARV. L. REV. 1497 (1983) (arguing that most efforts to reform women's lives have been constrained by view of market-family dichotomy).

104. See, e.g., Menkel-Meadow, supra note 12. 
ever may be wrong with the substance of that settlement, ${ }^{105}$ the results of that settlement must be compared to no settlement at all, or what might have occurred in adjudication, which in that case likely would have meant many years of waiting to be heard; a particularly harsh consequence for those claimants who were dying and might not have received legal relief.

Thus it is not "publicity" of the settlement that is the key to reform; what is necessary is a set of standards for scrutinizing both the settlement process and the settlement outcome. I have argued for a multitiered inquiry into such settlements, first when the negotiations begin (through such standards as adequacy of counsel, and proper consent to representation by class representatives), and then again when the negotiation is concluded (closer scrutiny of the substantive justice of the outcome, at least in those cases, like class action settlements, which require court approval or in which court approval is sought by the parties). ${ }^{106}$ In situations in which mass numbers of cases affect the functioning of the public litigation system or the public interest is obviously involved or implicated in court action (such as in the seeking of court approval of the Justice Department settlement in the Microsoft antitrust litigation), ${ }^{107}$ appropriate scrutiny of the settlement is in order.

This scrutiny is different, however, than requiring that all aspects of a complex and difficult negotiation occur in public. Even in the breast implant cases, in which there was greater publicity and more open representation of various subclasses of litigants, most of the actual negotiations (at which confidential financial data and litigation projections were discussed) were conducted in private. ${ }^{108}$ Free, open, and candid assessments of claims and offers of settlement on both conventional and more creative "problemsolving" bases are not likely to occur in the public eye for a number of reasons. For me, the key in evaluating when and how settlement should occur is not a question of publicity or confidentiality, but one of appropriate substantive and process "justice" standards, taking account of the interests of both the parties-disputants and others who are likely to be affected by the outcome, including in some cases, the whole polity. Given the extent to which important public issues are covered in the media today, total secrecy is less possible. Press coverage and open court hearings in

105. Critics argue that future claimants with pleural thickening and no current physical impairments have fared less well than current clients with such thickening whose cases were settled as part of a different settlement. Thus, the claims are that there were both conflicts of interests and collusion in the mass tort settlement of 20 asbestos producers (CCR) with tens of thousands of asbestos claimants. See Susan Koniak, Feasting While the Widow Weeps: Georgine v. Amchem Products, 80 Cornell L. Rev. 1040 (1995).

106. See Menkel-Meadow, supra note 12, at 1217-19.

107. United States v. Microsoft Corp., 159 F.R.D. 318 (D.D.C.), rev'd, 56 F.3d 1448 (D.C. Cir. 1995) (per curiam).

108. In re Silicone Gel Breast Implant Prods. Liab. Litig., No. Civ.A.CV-94-P-11558-S, 1994 WL 578353 (N.D. Ala. Sept. 1, 1994). 
prominent cases do facilitate the kind of public discourse Professor Luban suggests. ${ }^{109}$

\section{SETTLEMENTS OFTEN PROVIDE GREATER, NOT LESSER, POSSIBILITIES FOR JUST RESULTS}

Much of the critique of settlement rests on claims that negotiated settlements, more than adjudicated claims, will be determined by the raw bargaining power of one party over another. Assumptions abound here that power imbalances do not occur at trial, or if they do, they can be corrected by the neutral third party cloaked in a judge's robe. ${ }^{110}$ Yet several commentators have argued that without a neutral third party watching their behavior, negotiators ought to adhere to a higher standard of ethical care and concern for the other, behaving in a trustworthy manner and not agreeing to unconscionable results. ${ }^{111}$ Others have argued that certain forms of settlement processes, particularly mediation, are most effective at dealing with power imbalances and correcting information asymmetries by using a neutral third party to guide the process. ${ }^{12}$ Both the scholarly and professional literature on mediation processes more explicitly address the issue of how to take account of, deal with, and "balance" power inequalities during the actual mediation process. ${ }^{113}$ Given

109. It should be noted that none of these cases is "over." All are still pending in trial or appellate courts or await further agency action. Indeed, one could argue that journalistic attention to these cases has expanded the nature of the public discourse by including more members of the general public in the debates about the cases, rather than leaving the issues only to the lawyers and judges involved.

110. Both Owen Fiss and Richard Delgado make the explicit claim that judges will neutralize power imbalances in the courtroom by questioning witnesses or reminding the parties of their duties to act fairly. See Delgado et al., supra note 3, at 1368-69; Fiss, supra note 1 , at 1077 .

111. See, e.g., Murray L. Schwartz, The Professionalism and Accountability of Lawyers, 66 CAL. L. REV. 669 (1978) (attempting to set out code of conduct for lawyer acting as client representative outside of the courtroom setting); Geoffey C. Hazard, Jr., The Settlement Black Box, Paper delivered at Boston University Law School (Oct. 1994) (on file with The Georgetown Law Joumal) (discussing inadequate representation claims in settlement context). Attempts to formalize such standards in the attorneys' code of ethics, the $A B A M o d e l$ Rules of Professional Conduct, were ultimately unsuccessful.

112. See Jennifer G. Brown \& Ian Ayres, Economic Rationales for Mediation, 80 VA. L. REV. 323 (1994) (suggesting mediators can decrease impact of power imbalance by controlling flow of parties' private information); Albie Davis \& Richard A. Salem, Dealing With Power Imbalances in the Mediation of Interpersonal Disputes, 6 MEDIATION Q. 17 (1984); Howard Raiffa, Post-Settlement Settlements, in Negotiation TheORY AND Practice 323 (J. William Breslin \& Jeffrey Z. Rubin eds., 1991) (proposing scheme in which mediator proposes second settlement attempt to satisfy both parties).

113. See BUSH \& Folger, supra note 9, at 262-71 (describing mediation training that encourages empowerment); JonATHAN G. SHAILOR, EMPOWERMENT IN DispuTE MEdiATION: A CRITICAl ANALYSis of COMMUNiCATION (1994) (analyzing roles of empowerment and neutrality in mediation); William URY, GetTing Past No: Negotiating With Difficult PEOPLE (1991) (setting out negotiation strategies); Samuel B. Bacharach \& Edward J. Lawler, Power Dependence and Power Paradoxes in Bargaining, 2 Negotiation J. 167, 171-73 
the sometimes vast disparities of resources in the formal litigation arena, it seems odd to argue that adjudication is a better democratic leveler. Perhaps this would be true if most cases were heard by Fissian judicial power balancers, but even in those few cases that are heard by judges (and juries), it is often private (not public) resources, rather than justice or evenly matched "public discourse," which control case presentation, mobilization of proof, and thus, victory. ${ }^{114}$ Indeed, it has often struck me as somewhat ironic that one of the consequences of the Due Process revolution $^{115}$ has been the growing expense, complexity, and formality of hearings that have made some forms of adjudicative and administrative justice more expensive and remote to would-be claimants. ${ }^{116}$

Furthermore, recent commentators have noted the possibilities of some forms of settlement processes to provide greater, rather than lesser, opportunities for direct conversation, confrontation, and catharsis than court hearings. ${ }^{117}$ Judge Weinstein has spoken of the need for tort victims to express their pain and anger and has suggested that some forms of ADR may fulfill this need better than either formal court hearings (which may be impossible in mass cases) or attorney-negotiated settlements in which the actual parties have little opportunity to participate. ${ }^{118}$ My own experience as an arbitrator in the Dalkon Shield Litigation Trust suggests to me that private hearings in which claimants can tell their stories (when, as in those cases, the stories are of deeply personal and private matters) directly to a representative of the "defendant" with a third party present serve both cathartic and justice functions that are ill-served by overly formal and public hearings (which discourage some claimants from pursuing their claims) and by totally lawyer-dominated, bilateral negotiations in which

(1986) (analyzing power relationship based on dependence); Leo F. Smyth, Intractable Conflicts and the Role of Identity, 10 NEGOTIATION J. 311, 314 (1994) (discussing various means of altering power relationship between parties). See generally Lerman, supra note 2, at 102-06 (discussing how informal settlement process can be made sensitive to power imbalances).

114. See generally Marc Galanter, Why the "Haves" Come Out Ahead: Speculations on the Limits of Legal Change, 9 LAW \& SOC'Y REV. 95 (1974) (noting that repeat players in litigation have great strategic and distributional advantages in adjudication).

115. See, e.g., Goldberg v. Kelly, 397 U.S. 254 (1970) (granting due process protections to welfare recipients); $c f$. Symposium, The Legacy of Goldberg v. Kelly: $A$ Twenty Year Perspective, 56 BROOK. L. REV. 729 (1990) (evaluating current state of due process protections).

116. Of course, the impulses behind the procedural revolution were actually a desire for greater substantive justice. Cf. Martha F. Davis, Brutal NeEd: Lawyers and the WELFARE Rights MOVEMENT, 1960-1973 (1995) (tracing history of welfare and due process reform); Sylvia A. Law, Some Reflections on Goldberg v. Kelly at Twenty Years, 56 BROOK. L. REV. 805, 819-20 (1990) (citing Justice Brennan's view that situation involving "brutal poverty" required hearing).

117. See BUSH \& FOLGER, supra note 9, at 145-74 (describing how mediators should encourage parties to tell their stories as means of empowerment).

118. See Weinstein, supra note 20 , at $47-48$ (suggesting application of communitarian and communicatarian ethics in some mass tort cases). 
parties may have little participatory role. Thus, not all settlement or settlement processes are the same, and claims that either adjudication or public settlement will better serve all party "justice" interests are overly simplistic. ${ }^{119}$

To the extent that certain kinds of settlement processes include more participation by the parties, they may also facilitate greater democratic participation in the legal system than the stylized ritual dominated by lawyers that is the formal adjudication system. To the extent that at least some forms of facilitated settlement, including mediation, minitrials, and some settlement conferences, involve greater, rather than lesser, participation from the actual disputants, "control" of the dispute by the parties involved may make some forms of dispute resolution more responsive to parties', rather than professionals', interests. Especially when some of the forms of facilitated negotiation and settlement permit participation by more than just two parties (i.e., multiparty and public policy dispute mediations), ${ }^{120}$ direct conversation, confrontation, and "discourse" of all parties actually involved in a dispute will be far richer and more participatory than the two-sided conventional adversary mode. ${ }^{121}$

When used flexibly and with sufficient information, "appropriate dispute

119. Critics, like Richard Delgado, who suggest that only formal or public proceedings can satisfy both party and system needs for confrontation of wrongdoing seem to be (somewhat ironically in Delgado's case) ignoring the claims that narratives and storytelling (which can be told in greater contextual complexity in informal proceedings) may serve important functions in the recognition of harm and empathic responses to emotional, as well as legal, claims and harms. See, e.g., Richard Delgado, Storytelling for Oppositionists and Others: A Plea for Narrative, $87 \mathrm{MICH}$. L. REV. 2411 (1989) (examining use of stories in struggle for racial reform); see also Patricia J. Williams, The Alchemy of RaCE and Rights (1991) (presenting essays on race and gender in narrative form); Kathryn Abrams, Hearing the Call of Stories, 79 CAL. L. REV. 971 (1991) (studying use of feminist narratives); Toni M. Massaro, Empathy, Legal Storytelling, and the Rule of Law: New Words, Old Wounds?, 87 MICH. L. REV. 2099 (1989) (advocating use of empathy and stories in legal scholarship); Carrie MenkelMeadow, The Power of Narrative in Empathetic Learning: Post-Modernism and the Stories of Law, 2 UCLA Women's L.J. 287 (1992) (reviewing PATrica J. Williams, The Alchemy of RACE AND RIGHTS (1991)). For a powerful argument about the ironies of Delgado's anti-ADR positions and his claims for narrative and storytelling, see generally Dana $R$. Carter, From Mali to America: Looking At Alternative Dispute Resolution as a Place for Legal Narrative, Empathy and Understanding (1994) (unpublished manuscript, on file with The Georgetown Law Journal).

120. See generally Lawrence Susskind \& Jeffrey L. Cruikshank, Breaking the Impasse: Consensual Approaches to Resolving Public Disputes (1987) (describing and advocating negotiated approaches to consensus building); Gary Goodpaster, Coalitions and Representative Bargaining, 9 OHIO ST. J. ON DISP. RESOL. 243 (1994) (describing bargaining dynamics of coalitions).

121. In another paper, I have argued that adversary discourse, of the sort Luban extols in his paper, may actually thwart democratic and rigorous discourse. See generally MenkelMeadow, supra note 58. Not all questions have only two sides, and the adversarial process (and the debate mode) are not necessarily the best ways to illuminate complex, multifaceted issues. Consider health care reform, our policy in Bosnia, and affirmative action as some examples. 
resolution" allows parties to choose how they want their dispute resolved. Thus, any argument for adjudication over settlement must explain why placing the disputing apparatus in the hands of professionals, over the disputants, is more democratic. ${ }^{122} \mathrm{I}$ issue this challenge with several important caveats. First, not all settlement processes reflect this ideology of party determination or control. Indeed, as I have argued elsewhere, ${ }^{123}$ current use of some forms of ADR in the courts has resulted in cooptation of some of the party control values; feeling pressure to speed case processing, courts treat ADR bureaucratically and sometimes mandatorily, reducing party choice about process. When, however, parties (and their lawyers) are given an informed choice about different ways to resolve their disputes, such "multidoor" courthouses would seem to be far more "democratic" than adjudication or a coerced "public" settlement by allowing parties to consider what process seems most appropriate for their dispute. ${ }^{124}$ Parties (with the expert advice of lawyers) ${ }^{125}$ can decide how much "public discourse" or confidentiality they need to resolve their dispute, how much direct confrontation or conversation they want with the other side, and how much flexibility they want to work out possible solutions that a court would not be authorized to award. Thus, both party choice about

122. See generally BUSH \& FOLGER, supra note 9 (arguing that disputants can be "transformed" by mediation ethically, politically, humanistically, and morally, through more direct communication with each other, in ways that they are not affected by more formal adjudicatory processes).

123. See generally Menkel-Meadow, Pursuing Settlement, supra note 8, at 18-30 (discussing difficulties of incorporating ADR into adversary system); Carrie Menkel-Meadow, The Future of Civil Litigation; Dream or Nightmare? Lessons From the American Experience, in Shaping the Future: New Directions in Legal Services (Roger Smith ed., 1995); Carrie Menkel-Meadow, The Many Ways of Mediation: The Transformation of Ideologies, Paradigms, and Practices, 11 Negotiation J. 217 (1995) (reviewing accomplishments and potential of mediation in practice).

124. There is obviously an important issue about how to choose a process when the parties differ among themselves about which process to use. See, e.g., Stephanie Smith, Obtaining Maximum Benefit from ADR Phone Conferences, Ass'N Bus. TRIAL L. REP., Mar. 1995, at 1-2 (describing counseling by court ADR administrators).

125. Lawyers may, by the way, have conflicting interests in counseling which processes are best for the parties. Not only does the contingent fee structure affect incentives for lawyers to treat cases in particular ways, see Murray L. Schwartz \& Daniel J.B. Mitchell, An Economic Analysis of the Contingent Fee in Personal-Injury Litigation, 22 STAN. L. REV. 1125 (1970) (concluding that contingent fees do not necessarily align interests of lawyers and clients), but different settlement processes provide different financial incentives for lawyers as well. A streamlining Early Neutral Evaluation Program, for example, may result in fewer depositions and cut down the hours available for billing. In the Early Neutral Evaluation Program utilized by the Northern District of California, lawyers for both parties meet with third party neutrals (volunteer lawyers) to present facts and key issues in dispute to obtain an early assessment of the case (both for settlement purposes and to set discovery schedule). See Rosenberg \& Folberg, supra note 39. New billing practices imposed by powerful clients have created greater financial incentives for the settlement process. See, e.g., Robert E. Litan \& Steven C. Salop, Reforming the Lawyer-Client Relationship Through Alternative Billing Methods, 77 JUDICATURE 191 (1994) (describing alternatives to hourly billing such as blended partner/associate rates and fixed fees). 
process and the particular kinds of solutions chosen are at least theoretically, if not always in practice, more democratic (at least for the parties) than the compulsory adjudication or public settlement process critics like Luban and others suggest.

\section{E. SETTLEMENTS MAY PROVIDE DEEPER AND RICHER ACCESS TO JUSTICE}

Some forms of ADR and settlement policies also provide the potential, if not yet the reality, of greater access to justice. If a variety of ways of resolving disputes becomes available, not all parties will line up for the same processes or choose the same dispute resolvers or rule enunciators. Indeed, some judges have welcomed their roles as "social justice bureaucrats" or "public problem solvers," helping parties choose an appropriate process or becoming more active in case handling and settlement. ${ }^{126}$ If properly monitored and regulated (and that is one of the roles of the academic critic like Professor Luban and myself, across our similar concerns but factual and philosophical differences), these new processes offer the potential of making more, rather than less, justice available, both in terms of processes available and the variety of outcomes that may be achieved.

The key issue in the differences between Professor Luban and myself then, seems to turn on "democratic" dispute processes for whom-the disputants themselves or the larger society with a potential interest in how particular disputes are resolved. This difference, if important, may also be somewhat intractable. It is reflected in the current differences of expert opinion on whether or not the settlements of mass torts like asbestos and breast implants through private class action settlements were appropriate or not. ${ }^{127}$ For me the answer lies not in whether the process used should have been full adjudication or settlement, or even if the negotiations should have been conducted in public or not. The key issue is by what standards should we (the courts, the public, and academic critics) judge the processes chosen and the ultimate results. When is a settlement just and to whom must it appear so?

\section{Making The Case For Better Settlements in Both the PRivate ANd Public Realm}

To recapitulate, I have tried to argue that settlements are not inherently inferior to adjudicated outcomes, as critics like Professor Luban seem to

126. Such judges include Jack B. Weinstein (E.D.N.Y.), Richard Ensalen (W.D. Mich.), Arthur Spiegel (S.D. Ohio), Thomas Lambros (N.D. Ohio), and Sam Pointer (Ala.) to name a few. See Menkel-Meadow, supra note 12, at 1183; see also Resnik, Managerial Judges, supra note 4, at 376-77 (surveying judicial participation and interest in ADR); Hornby, supra note 9, at 27-28 (discussing changing role of judges with advent of ADR).

127. See generally Cornell Symposium, supra note 12. 
suggest. (Even with his more narrowed focus on privacy in settlements, Luban continues to see settlements as a necessary evil.) Just as adjudication is often romanticized when set off against settlement, and its better features are elaborated, I have here tried to make the following arguments on behalf of the "best" aspects of settlement:

1. Settlements that are in fact consensual represent the goals of democratic and party-initiated legal regimes by allowing the parties themselves to choose processes and outcomes for dispute resolution.

2. Settlements permit a broader range of possible solutions that may be more responsive to both party and system needs. ${ }^{128}$

3. What some consider to be the worst of settlement, that is, compromise, may actually represent a moral commitment to equality, precision in justice, accommodation, and peaceful coexistence of conflicting interests.

4. Settlements may be based on important nonlegal principles or interests, which may, in any given case, be as important or more important to the parties than "legal" considerations. Laws made in the aggregate may not always be appropriate in particular cases, and thus settlements can be seen as yet another "principled" supplement to our common law system.

5. Settlement processes may be more humanely "real," democratic, participatory, and cathartic than more formalized processes, permitting in their best moments, transformative and educational opportunities for parties in dispute as well as for others.

6. Some settlement processes may be better adapted for the multiplex, multiparty issues that require solutions in our modern society than the binary form of plaintiff-defendant adjudication.

7. Despite the continuing and important debates about discovery and information exchange in the litigation process, some settlement processes (mediation and some forms of neutral case evaluation and scheduling) may actually provide both more and better (not just legally relevant) information for problem-solving, as well as "education" of the litigants.

8. When used appropriately, settlement may actually increase access to justice, not only by allowing more disputants to claim in different ways, but also by allowing greater varieties of case resolutions.

128. I have not dealt here with Luban's significant claim that consensual two-party settlements may externalize the costs and detriments of settlements onto "innocent" third parties, such as taxpayers or others. This is an important point that requires both more theoretical elaboration and empirical study. 
Thus, in its most idealized forms, settlement can be defended as being participatory, democratic, empowering, educative, and transformative for the parties.

Professor Luban would likely counter with-so what? Even if parties are satisfied with settlements, ${ }^{129}$ there is a public interest in every, or at least many, private settlements. Furthermore, he would say, not all settlements conform to the ideal type I have suggested here and elsewhere. Analytically, these are two separate questions, and thus they should be separately considered: First, which "settlements," no matter how good they are for the parties, should be subject to public scrutiny? Second, what factors can we use to assess whether a settlement is properly arrived at, both for the parties concerned and for whatever other interests may be implicated in the settlement? These are far more complicated questions, and I do not think they lend themselves to easy answers. In closing this essay I will suggest a few of my own thoughts, but I think it more important that Professor Luban and I have set an agenda of issues to discuss and more fully explore than that either one of us (or any of the other commentators on this subject) have got it right.

\section{A. TELLING A GOOD FROM A BAD SETTLEMENT}

Taking the second question first (because it is easier and I have written about it before), ${ }^{130}$ it is important to consider settlements that depart from the ideal form that I have sought to defend here. If settlements are not consensually arrived at (through mandatory and coercive court programs, ${ }^{131}$ or because lawyers dominate decisionmaking, ${ }^{132}$ or because the choice is not real when one cannot afford to wait to litigate, ${ }^{133}$ or because there are such vast disparities between the parties that "consent" cannot

129. We have highly contradictory data on this point. Most satisfaction studies show high rates of satisfaction with almost any process studied, yet other studies suggest that parties are happier with fora in which a third party does render a decision, like arbitration. See, e.g., E. Allan Lind et al., In The Eye of the Beholder: Tort Litigants' Evaluations of Their Experiences in the Civil Justice System, 24 LAW \& SoC'Y REV. 953 (1990). (reporting that satisfaction levels varied with perceptions of procedural fairness and expectations of outcomes and costs).

130. See Menkel-Meadow, supra note 9, at 760-61.

131. See Lisa Bernstein, Understanding the Limits of Court-Connected ADR: A Critique of Federal Court-Annexed Arbitration Programs, 141 U. PA. L. REV. 2169 (1993) (arguing that mandatory court-annexed arbitration programs do not increase access to justice and may decrease access to justice for poorer litigants); Lucy V. Katz, Compulsory Alternative Dispute Resolution and Voluntarism: Two-Headed Monster or Two Sides of the Same Coin?, 1993 J. DISP. RESOL. 1 (surveying extent of compulsory ADR).

132. See Mark Spiegel, Lawyering and Client Decisionmaking: Informed Consent and the Legal Profession, 128 U. PA. L. REV. 41 (1979) (criticizing lawyer domination of decisionmaking and advocating application of informed consent doctrine to lawyer-client relationship).

133. With "three strikes and you're out" legislation in the criminal arena, there will be fewer and fewer civil courtrooms available in the "multidoor" courthouses of California. 
be given), ${ }^{134}$ then we must question whether such a settlement should be enforced. As ADR becomes institutionalized in courts, there is a danger that people will "consent" to settlements because they feel they have no real alternative. ${ }^{135}$ If there is no consent, an important value justifying settlement is absent. ${ }^{136}$

If settlements do not track the law because other interests are deemed more important by the parties, then we should not intrude upon a private settlement, unless that settlement violates another law of public importance. Thus, while I claim that law is not necessarily the measure of a good settlement (and parties may choose to ignore particular legal endowments when bargaining), ${ }^{137}$ law may tell us when we have a bad settlement. ${ }^{138}$

\section{B. WHEN SETTLEMENTS SHOULD BE PUBLIC}

Professor Luban concludes his essay by suggesting that we need certain settlements to be conducted in the public realm because they serve the "public-life conception of legitimacy" of the legal system. Though he cites the recent court-approved asbestos settlement in Georgine and the courtdenied settlement in the Microsoft antitrust action as examples of cases that should have been conducted "in public," he fails to specify the criteria for determining when a case belongs in the public realm. This, I believe, is our next intellectual duty, and I find it no easier than the task of deciding which cases should be allocated to which processes. ${ }^{139}$ One could argue

134. This raises all of the issues implicated in paternalistic judgments. See David Luban, Patemalism and the Legal Profession, 1981 WIS. L. REV. 454, 460 (arguing that in some cases paternalism of lawyers toward clients is justified).

135. As a mediator in trial courts in Los Angeles, I have seen many cases in which parties settle out of frustration, not consent, and on the basis of eliminating a nuisance, not on the basis of any principle. See Carrie Menkel-Meadow, Lawyer Negotiations: Theories and Realities-What We Learn from Mediation, 56 MoD. L. Rev. 361 (1993) (reporting experiences with real world behavior of participants in mediation clinic).

136. It is the question of client consent to settlement that makes approval of the recent mass tort class action settlements so difficult. How can we measure the consent of a party who may not even know he is injured? See the discussion of Georgine, supra note 90.

137. For example, parties may agree to pay more or less than court-suggested guidelines in spousal or child support. See Gary Friedman, A Guide to Divorce Mediation 48-50 (1993).

138. The most difficult aspect of assessing settlements here is that when settlements are totally private (i.e., the parties have chosen private judges or mediators or have simply settled on their own), there is no way of assessing whether any of the aforementioned conditions have been violated. Of course, adjudication may also shift costs or effects to "innocent" third parties, and there are no formal mechanisms for assessing whether that is relevant to any judgment.

139. Although I attempted some time ago to specify some of the contextual factors to be considered in how a case should be negotiated, see Carrie Menkel-Meadow, Legal Negotiation: A Study of Strategies in Search of a Theory, 1983 AM. B. Found. RES. J. 905, 927-28, I have abandoned any notion that we can assign cases ex ante to particular processes. $C f$. Frank E.A. Sander \& Stephen B. Goldberg, Fitting the Forum to the Fuss: A User-Friendly Guide to Selecting an ADR Procedure, 10 NEgotiation J. 49 (1994) (attempting to identify whether case is suitable for ADR). 
that although both of these cases did receive public attention and debate in the widespread press coverage that has accompanied the litigation, it is clear that the settlement negotiations themselves were, in both cases, conducted largely in private and were shrouded in secrecy until concluded. Because I disagree with Professor Luban that such settlement negotiations can be conducted effectively in public (Would Bill Gates voluntarily disclose Microsoft's future marketing plans in a public negotiation about what the appropriate market share in the software industry should be?), the crucial questions for me are: When and how settlements should become public, and what scrutiny should be given to them?

I suggest that we do have some measures for deciding this question. As Judge Sloviter's decision in Rittenhouse makes clear, when the parties themselves seek court imprimatur and approval of a settlement, then secrecy, at least of the terms of the settlement, must be presumed to be waived in the absence of some other important legal policy. Similarly, in the case of class action settlements requiring court approval under Federal Rule of Civil Procedure 23(e), courts must engage in some scrutiny of the adequacy of counsel and the reasonableness of settlement. I have argued that this scrutiny should include closer looks at both process and substantive measures of the settlement process, ${ }^{140}$ and Judge Schwarzer has drafted a new Rule 23(e) that attempts to codify the factors for that scrutiny. ${ }^{141}$ Nevertheless, there will be whole classes of cases that may seem to implicate "public interests" that are not formally before the courts. How then do we decide which settlements should be exposed to public scrutiny? Like Professor Luban, I am persuaded that certain settlements so implicate the interests of those beyond the dispute that some "public" exposure of such cases may be a necessary part of our democratic process. As I have suggested elsewhere, mass torts actions, by their very nature, fall into this class of "public" cases not only because they affect many potential victims, but because the sheer numbers of these cases have had a significant impact on our justice system. ${ }^{142}$

Nevertheless, sheer numbers is not really an adequate test. Many consumer cases have involved substantial numbers of people and have been adequately dealt with by more or less private settlements, either on a class or individual basis. Employment discrimination cases, which some see as important "public interest" cases that should be "tried" in public are, to many victims of employment discrimination, cases that they want very much constrained to private settlements for fear of exposure of complicated employment records and history. What makes the Georgine and Microsoft cases so interesting is that they raise questions about when party

140. See Menkel-Meadow, supra note 12, at 1217-19.

141. See.Schwarzer, supra note 12 , at 843.

142. See Menkel-Meadow, supra note 12, at 1187. 
consent is not enough and about what path to follow when third party objectors (excluded plaintiffs' lawyers in Georgine) or a neutral third party (the judge in Microsoft) seek to disrupt party consent and call our attention to interests the negotiating parties may have chosen to avoid or ignore.

Thus, I conclude by suggesting that Professor Luban has raised some important questions for us, but he has not fully answered or elaborated them. Empirical research does not yet support the notion that judicial intervention in settlement necessarily makes for better settlements, ${ }^{143}$ yet we know that settlement has certainly become the most common form of dispute resolution. By seeking to defend settlement at its best and to provide some philosophical and democratic justification for it, I hope to have illuminated some criteria by which we can judge when settlements fulfill their purpose and when they fall short. At the core of this assessment is a prior question about "possession" of the dispute. If the parties "own" their dispute, then party consent must be our democratic justification for settlement. If someone other than the parties (affected third parties, the public) have an interest in the dispute, we must consider ways to assess how our party-initiated and party-controlled legal system can be adapted to take account of such interests and how those interests can be raised. Because not all settlement processes are the same, we must consider how much of the settlement process we will need to scrutinize-the process itself? Only outcome fairness? For whom are cases settled?

Thus, while I join with Professor Luban in thinking that a "jurisprudence of settlement" is waiting to be invented and that it must be debated, as here, in the "public realm," I believe that jurisprudence will be complex and long in coming and we have "only just begun" to specify its questions.

143. See generally Galanter \& Cahill, supra note 13. 